\title{
Learner Autonomy as an Element in Chinese Education Reform: A Case of English Language Subject
}

\author{
Jinjin $\mathrm{Lu}^{1} \&$ Yingliang Liu ${ }^{2}$ \\ ${ }^{1}$ Research Institute for Professional Practice, Learning and Education, Charles Sturt University, Australia \\ ${ }^{2}$ School of Foreign Languages, Wuhan University of Technology, Wuhan, China \\ Correspondence: Jinjin Lu, Research Institute for Professional Practice, Learning and Education, Charles Sturt \\ University, Panorama Avenue, Bathurst NSW 2795. E-mail: jlu@csu.edu.au
}

\author{
Received: October 17, 2015 Accepted: February 8, 2016 Online Published: February 10, 2016 \\ doi: 10.5539/elt.v9n3p33 URL: http://dx.doi.org/10.5539/elt.v9n3p33
}

\begin{abstract}
Enhancing students' learning autonomy has been emphasized in the current round of English curriculum reforms by the Ministry of Education (MOE) in China. The initial aim of the new guidelines was developed to enhance students' English proficiency to better fulfil their basic education (Nine-year compulsory education). However, up until now, very little is known about the quality of students' basic education and their learner autonomy development. This paper uses the English language subject as a case to examine the relationship between the different locations of students' attendance of their basic education and their learner autonomy development at university level. The result shows that secondary schools' locations play a more important role in students' learner autonomy development at university. A 'Have A Go' model is proposed to improve students' transition between high schools and universities in the English language learning process.
\end{abstract}

Keywords: learner autonomy, basic education curriculum reform, knowledge transition, 'Have A Go' model

\section{Introduction}

The concept of 'learner autonomy' was introduced into China by western scholars. However, the concept viewed by Chinese educators differs from the original concept that relates to the western liberal education. In Europe, autonomy is linked with politics, power and governance in education (Eurydice, 2008). Generally, the development of learners' personal autonomy is an important goal of education in the West (Benson, 2011; Dam, 1995; Holec, 1981). However, in China, with a long history of Confucianism, the acceptance of changing the roles of teachers and students in respect of developing autonomy could be challenging. These include a significant shift from the teacher -dominant classroom to a more student-centered classroom, traditional grammar-translation teaching method to the blended use of Self-Access Learning Centers, and a policy based curriculum guideline initiated by the MOE. All these challenges are closely related to learner autonomy as it is an essential element in the current round of China's Basic Education Curriculum Reform and College English Curriculum Reform in 2004.

English, as a foreign language, has been emphasized in all educational levels since the restoration of the College Entrance Examination in mainland China. From primary education to doctoral education, English scores in all kinds of examinations were like a compass to direct students in their learning process. Consequently, students and teachers are more likely to put effort in writing and reading practice rather than all-round development in the four language skills (Listening, Speaking, Writing and Reading) because most of the English examination papers were designed to evaluate students' linguistic usage and literacy knowledge. With a purpose of strengthening students' comprehensive English skills, the MOE emphasized that the development of English language learning autonomy is essential not only for learning English language but also for their life-long learning.

\section{China's Basic Educational Reform}

As one of the largest developing countries, Chinese students' education is a long-term task confronting the Chinese government. Based on the report from the Ministry of Education (MOE) in 2013, the number of regular higher education institutions reaches to 2491 with more than 34 million students on campus. Although the number of regular primary and secondary schools also has slightly decreased to 235,369 and 80,797 respectively compared with that in 2012, the total number of students in primary and secondary schools still reached over 138 
million $^{1}$. With a large population of school-age children, promoting and enhancing the quality of basic education is an ongoing process that needs focusing upon without any delay.

At the turn of the $21^{\text {st }}$ century, the MOE initiated a top-down Basic Education Curriculum Reform. Generally, the current round basic education reform has a dedicated reference to every subject aimed to improve curriculum standard, teaching and learning methods, teacher development, and assessment and evaluation. A trial document was launched by the MOE with the specific guidelines in 2001. The main aims are listed as follows:

- To change the previous teaching method from 'imparting' knowledge to students to 'stimulating' students' interest to learn.

- To adjust the number of courses in schools to increase the choices of elective and comprehensive courses to improve students' quality development.

- To change the textbook contents to link with students' daily life and social development.

- To reduce the tendency to overemphasize the 'rote-learning' style and to address concerns on the development of students' practical abilities by using technological tools.

- To reduce the tendency to overemphasize the assessment form for choosing elite students and to pay more attention to students' all-round development.

- To release the governance of the curriculum management from the central government to the local governments. The shared governance is based on local schools, local government and the national educational committee.

The essential ideas of the MOE are to enforce two 'basics' into the classroom teaching and learning in the new Curriculum. That is, 'knowledge' and 'skills' are two correlated elements in life-long learning and the new Curriculum emphasizes that students should have abilities to transit what they have learnt from the class (knowledge) to what they can use in practice (skills). Ability in the transit process is important for the development of learner autonomy and collaborative learning skills (Hu, 2003; Lu, 2014; Paine \& Fang, 2006; Ryan, Kang, Mitchell, \& Erickson, 2009). Regarding the new Curriculum, different opinions were raised. According to Paine and Fang (2006), they argued that the new Curriculum has an ideal expectation on students in China.

The new curriculum aims at developing a new kind of ideal learner, one who loves learning, is able to solve problems in real-life situations through inquiry and creativity, and has the capacity to be a lifelong learner. This vision of a re-defined ideal student necessitates new expectations for what a qualified teacher does and what good teaching entails (p. 282).

Li and Ni (2012) utilised Mathematics as a case study to discuss the challenges that the teachers faced in the implementing of the new Curriculum. They believed that the new Curriculum pushed students and teachers towards "real-life applicability and hands-on participation" ( $\mathrm{Li} \& \mathrm{Ni}, 2012$, p. 9). Results from a large scale empirical study of investigating the new Curriculum reform implementation showed that " 72 percent of teachers report frequent use of lecture and 61 percent of teachers report frequent use of memorization and recitation in Gansu Province in China" (Sargent, 2011, p. 54). However, significant improvements have been found in the ICT development in China. (Zhang, Fang, \& Ma, 2010). Furthermore, with the implementation of the new Curriculum, teachers' professional development has progressed.

\subsection{The English Subject in the China's Educational Reform}

The position of the English course has been pivotal in the educational system in China. After the guidelines of the current China's Basic Educational Reform were launched, the English subject has been required to be taught from the higher grade in primary schools till the last year in senior high schools. More than this, English is a compulsory subject in higher education institutions and other adult learning programmes. The following figure shows the important position of the English subject in the educational system in China. 


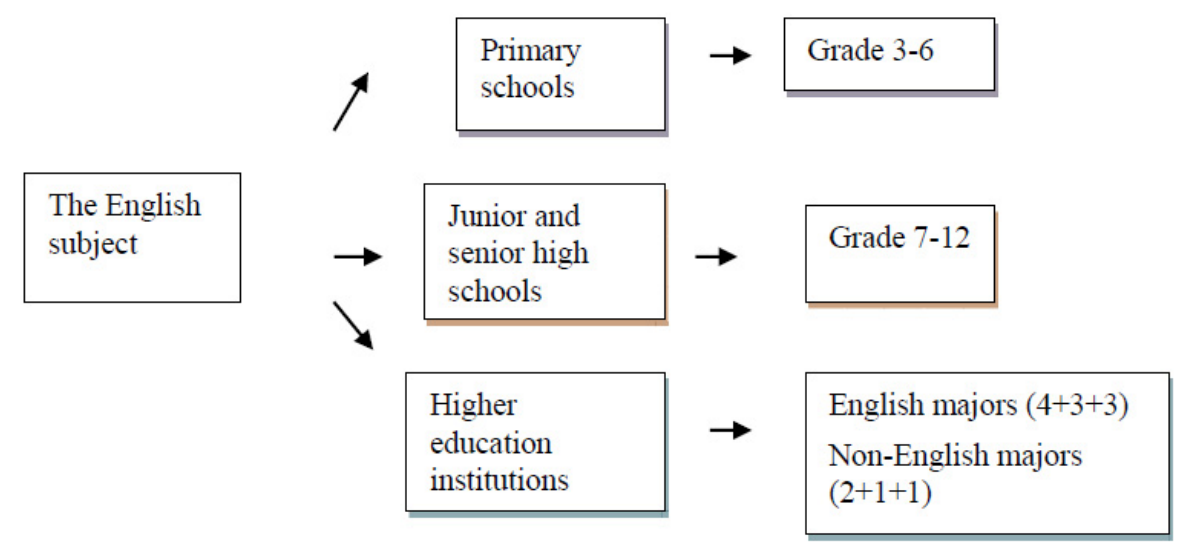

Figure 1. The English subject in China's educational system

Chinese students begin learning English from Grade 3 in public schools and continue until reaching university. When students come to the higher education institutions, for English majors, they need to learn English based on a four-year undergraduate programme and further if they pursue their study as postgraduate students, they need to continue learning English based on a three-year master's programme and a three-year doctoral programme. However, for non English majors, the English subject is only supplied for undergraduates in the first and second year and for master and doctoral students in their first year of study. Although the English subject has been implemented for all levels of schooling in China, the current Curriculum Reform has different purposes and aims in primary education, secondary education and higher education. The main purposes of English courses in the three levels are listed in the following Table:

Table 1. Purposes of English courses in the educational reform

\begin{tabular}{ll}
\hline Levels & Purpose \\
\hline $\begin{array}{l}\text { Primary } \\
\text { education }\end{array}$ & - To stimulate students' interest in learning \\
$\begin{array}{l}\text { Secondary } \\
\text { education }\end{array}$ & learning \\
& - To stimulate students' interest in order that students have confidence in language \\
& - To develop students' learner autonomy and to acquire effective learning strategies \\
& collaborative learning skills \\
& - To apply the skills into real-life and know how to transmit the knowledge into practice. \\
& - To have understandings of the differences between the western culture and Chinese \\
Higher & - To enhance students' imagination and creativity \\
education & - To enhance students' transition skills by using effective learning strategies \\
& 'mute' graduates. \\
& - To foster students' listening and speaking ability in order to reduce the 'deaf' and \\
& globalisation.
\end{tabular}

Table 1 shows that the main emphasises are to stimulate students' interest and understanding of language learning and to develop skills and knowledge that assist learner autonomy. Given the increased interest in learning, and competence in communication in English, students are able to develop transition strategies and consequently to enhance their autonomous learning abilities. 
Since the guidelines of the English Course Curriculum were launched in the early $21^{\text {st }}$ century (Ministry of Education, 2001, 2004), a substantial number of research studies have focused on exploring English language teaching and learning in various aspects in China, such as learning styles (Yang, Shi, Liu, \& Zhao, 2015), learners' motivation (Dörnyei, 2009; Gao, Zhao, Cheng, \& Zhou, 2007; Q. Zhang \& Kim, 2013), learning and teaching strategies (Lai \& Lin, 2015; Tang \& Tian, 2015; Zhao \& Coombs, 2012), and learner autonomy (Benson, 2011; Ma \& Ma, 2012; Stracke, 2012). Chow (1995) claims that Chinese students prefer to be taught by using traditional teaching methods, such as lectures, handouts and displays. This is supported by Rodrigues (2004), whose research indicates that Chinese learners have a preference in learning passively. Thompson and Gui (2000) assert that western teaching methods could not fit Chinese learners as there is a unique influence of Confucianism shared by the nation and they argue that this culture derives from preferences for rote learning. Throssell and Zhao (2011) also believe that Confucianism has a significant influence upon Chinese students' learning styles and methods utilised in the English language learning process. However, Wang and Moore (2007) undertook an empirical study to show that Chinese students located in two different places did not have homogenous approaches to learning.

According to Lu (2014), although implementing a 'student-centred' teaching method is required in the current curriculum reform, particularly, in the English subject reform, the teachers and students still faced significant challenges influenced by China's examination-oriented evaluation system. Having pressures from parents, schools and principals, on the one hand, English teachers are expected to give assignments to students to drill the grammatical skills; on the other hand, they are expected to work aligned with the requirements by the MOE to make students actively involved in the English activities. Also, Lu (2014) argues that a lack of transition studies between high schools and universities might result in students' lack of agency, motivation and self-regulation at university. From this point of view, the development of knowledge transition is essential for Chinese students but the current English language teaching practice seems to have difficulty in satisfying this need.

In general, although previous studies have focused on different aspects regarding ESL teaching and learning in China, most scholars used comparative studies to investigate Chinese participants' from Hong Kong, Taiwan, and other Asian countries. However, few empirical studies have focused on exploring students' learner autonomy development and their basic education locations in mainland China. In order to explore the relationship between students' basic education and their development of learner autonomy at the university level, three research questions were raised as follows:

1). What is the relationship between the location of students' primary and secondary schools and their development of learner autonomy at the university level?

2). What are the barriers to the development of learner autonomy in the practice in schools and universities?

3). What are the challenges of students' transition between high schools and universities?

\section{Method}

Mixed research methods were utilised in this study. Teddlie and Tashakkori (2010, p. 5) define the mixed method as "the broad inquiry logic that guides the selection of specific methods and that is informed by conceptual positions common to mixed methods practitioners (e.g., the rejection of "either-or" choices at all processes)". The use of mixed research methods yields richer data compared with using a single research paradigm. Moreover, numeric data from the survey and textual data from case studies can provide a data source for triangulation in the research study.

\subsection{The Study Design}

The present study is a large scale empirical study (which followed up on a pilot study in 2013) in the center of mainland China. In the first stage, a survey questionnaire was designed based on Holec's (1981, p. 3) influential definition of learner autonomy: "the ability to take charge of one's learning ... to have, and to hold, the responsibility for all the decisions concerning all aspects of this learning". According to Holec's definition, learners need to make decisions in terms of their own learning objectives, learning contents and progress, learning methods utilised, monitoring learning procedures, and learning evaluations required. The survey was designed to address the research aim and research questions. The first section was designed to investigate participants' background information, such as gender, ethnicity, and their basic education locations. From the second section to the sixth section, the questionnaire was designed according to the five specific criteria proposed by Holec (1981) to explore the views of the students' decision-making abilities in learning English. A five-item Likert scale was used to measure students' views from the extent of their agreement from ' 1 ' (Total Disagreement) to ' 5 ' (Total Agreement). 
In order to reduce the opportunities of misunderstandings with Chinese students, a bilingual independent back-translation method was adopted to translate the English into Chinese. This method is recognised as an effective way to test the accuracy and validity of cross-cultural research studies (Epstein, Osborne, Elsworth, Beaton, \& Guillemin, 2015; van de Vijver \& Leung, 1997). The English version of the questionnaire was translated into Chinese by the first author, who is fluent in both English and Chinese and who specialises in the research field of language learning and teaching. The questionnaire was independently back-translated by three other scholars with excellent knowledge of Chinese and English. Bilingual scholars were invited to participate in the interpretative process, as they play an important role in ensuring the validity and reliability of the research tool (Epstein et al., 2015). General linguistic agreement between the first author and other three bilingual scholars was achieved. The wording of the Chinese version of the questionnaire reflected only minor differences. After the adjustments and recommendations of the three scholars and the research team members, the final Chinese version of the questionnaire was developed and sent to participants in their English classrooms.

At the second stage, the author used a case study approach to provide rich textural data in comparison with the numeric data obtained in the first stage. A case study approach was utilised as its exploratory and descriptive nature presents basic information (Bogdan \& Biklen, 1982). Most importantly, a case study method is regarded as "a research strategy which focuses on understanding the dynamics present within single settings" (Eisenhardt, 2002 , p. 8). As such, this qualitative approach is the most suitable for this study to provide further in-depth perceptions in this single contextual setting.

\subsection{Participants and Data Collection}

The data was collected between August 2014 and February 2015. At the quantitative stage, there were 400 university students initially involved in the questionnaire but finally 319 students completed and submitted. At this stage, the case study approach was utilised to investigate one university student and his English teacher from his secondary school. The textual data included their teaching and learning materials, the teacher's secondary school information, and their reflections. A narrative writing style was used to present the collected information to show natural and rich phenomenon that emerged.

\section{Results}

\subsection{Quantitative Stage}

The sample was composed of 175 male students and 144 female students attending a high rank comprehensive university in the central of China. They came from five main faculties: Humanity, Engineering, Science, Arts, and Technology. Also, regarding their years of studying at the university, the sample was divided into six categories. The largest number of participants was freshmen $(n=129)$, followed by masters $(n=115)$ and sophomores $(n=64)$. There were a smaller number of juniors $(n=2)$ and seniors $(n=5)$ involved in this study as most students attended professional practice out of campus when the data was collected. There were six $\mathrm{PhD}$ students volunteering to join the survey. Among these participants, their locations of completing theie basic education were investigated. The details are shown in the following figure:

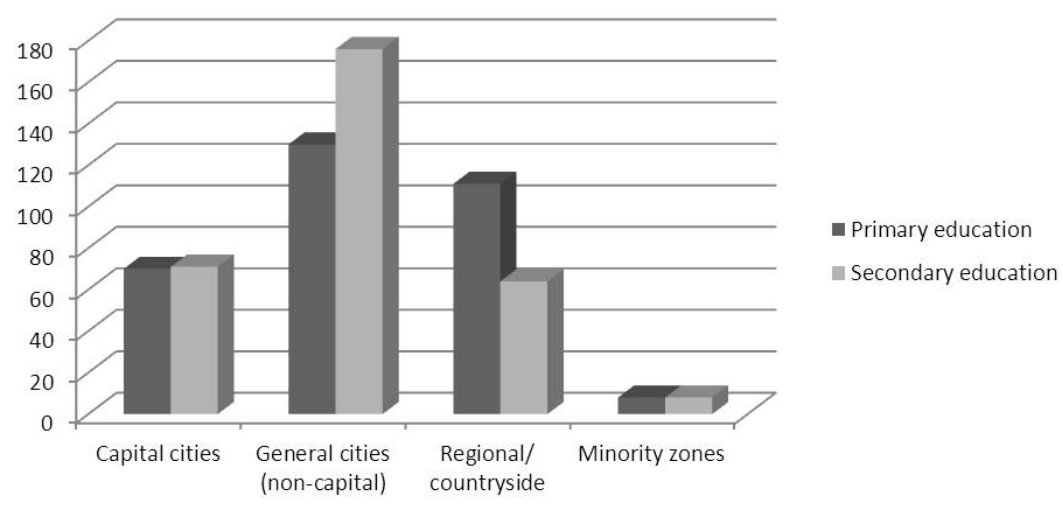

Figure 2. Locations of the participants' basic education

Figure 2 shows that most participants finished their primary education in general cities (non-capital) and regional areas in China. However, when children came to the age of attending secondary schools, a large number of 
students chose to complete their secondary education in cities instead of regional areas or in the countryside. The number of participants who finished their primary education in capital cities and minority zones did not change much compared with the number in secondary schools in these two categories. In order to answer the first question, SPSS version 22 was utilised in the data analysis process. Initially, the Kruskal-Wallis test was adopted to identify any significant difference between the four locations of students' primary and secondary schools and the participants' learner autonomy ability. If a statistically significant difference was found between the groups, then the Mann-Whitney $U$ test was adopted to find the difference.

Statistically significant differences were found within the two questionnaire items (Q9 and Q34) of learner autonomy ability influenced by the participants' primary school locations. All $\mathrm{p}$ values were less than .05 (Pallant, 2013). Question $9\left(\mathrm{X}^{2}=11.446, \mathrm{p}=.010\right)$ was designed to see whether the participants are responsible to make decisions on planning their own learning plans and Question $34\left(\mathrm{X}^{2}=8.538, \mathrm{p}=.036\right)$ asked whether they are able to identify their weakness after self-evaluation. In order to find out where the difference lies within the four categories of primary school locations, the Mann-Whitney U test was utilised. The results are presented in the following:

Table 2. Mann Whitney Test on Q9 and Q34

\begin{tabular}{ll}
\hline Questionnaire Items & $\begin{array}{l}\text { Statistically significant differences in groups (Primary school } \\
\text { locations) }\end{array}$
\end{tabular}

Q9. I can make decisions on English • Between capital cities ( $\mathrm{n}=70$, mean rank=104.74) and learning plans in and out of class. $\quad$ regional/countryside $(n=111$, mean $\operatorname{rank}=82.33)(U=2923.000$, $\mathrm{Z}=-2.918, \mathrm{p}=.004, \mathrm{r}=0.16)$

- Between general cities $(n=130$, mean $r a n k=129.71)$ and regional/countryside $(\mathrm{n}=111$, mean $\mathrm{rank}=110.80)(\mathrm{U}=6082.500$, $\mathrm{Z}=-2.200, \mathrm{p}=.028, \mathrm{r}=0.12$ )

\begin{abstract}
Q34. I monitor my learning process by - Between capital cities $(\mathrm{n}=70$, mean rank=100.62) and self-evaluation and $\mathbf{I}$ am able to identify regional/countryside $(\mathrm{n}=111$, mean $\operatorname{rank}=84.93)(\mathrm{U}=3211.500$, my weaknesses.
\end{abstract}

- Between general cities $(\mathrm{n}=130$, mean $r a n k=131.36)$ and regional/countryside $(\mathrm{n}=111$, mean rank=108.86) $(\mathrm{U}=5868.000$, $\mathrm{Z}=--2.715, \mathrm{p}=.007, \mathrm{r}=0.15)$

Table 2 shows that statistically significant differences were only found between participants who finished their primary education in capital cities and regional areas, and between those in general cities and regional areas on the two question items. No statistically significant differences were found within other groups regarding the participants' primary locations on their learner autonomy ability at university.

The same analysis techniques were utilised on examining the relationship between students' secondary school locations and learner autonomy ability at university. After using the Kruskal-Wallis test, eight question items were found to have statistically significant differences influenced by the participants' secondary school locations. They are:

Q9. I can make decisions on English learning plans in and out of class. $\left(X^{2}=11.809, p=.008\right)$

Q12. I can make decisions on English learning objectives in and out of class $\left(X^{2}=9.101, p=.028\right)$

Q20. I choose online learning as a learning method to improve English $\left(X^{2}=7.830, p=.050\right)$

Q25 I am responsible for choosing English activities outside of class $\left(X^{2}=14.435, p=.002\right)$

Q26 I am responsible for monitoring English learning progress by using various strategies $\left(X^{2}=14.938, p=.002\right)$

Q29 I am responsible for correcting mistakes by myself $\left(\mathrm{X}^{2}=8.820, \mathrm{p}=.032\right)$

Q33 I evaluate my English learning regularly $\left(X^{2}=8.870, p=.031\right)$ 
Q36 I would like my English teachers to evaluate my English learning $\left(X^{2}=11.567, p=.009\right)$

The Mann-Whitney $U$ test was utilised further to find out which group is statistically significantly different from the other. The results are shown as follows:

Table 3. Mann Whitney U Test result

Questionnaire Items

Statistically significant differences in groups (Secondary school locations)

Q9. I can make decisions on English learning plans in and out of class.
- Between capital cities $(n=71$, mean rank=76.46) and regional/countryside $(n=64$, mean rank=58.62) $(\mathrm{U}=1671.500$, $\mathrm{Z}=-2.756, \mathrm{p}=.006, \mathrm{r}=0.15)$

- Between regional/countryside $(n=64$, mean $r a n k=34.55)$ and minority zones $(n=8$, mean rank=52.13) $(\mathrm{U}=131.000, \mathrm{Z}=-2.321$, $\mathrm{p}=.020, \mathrm{r}=0.13)$

Q12. I can make decisions on English learning objectives in and out of class.

- Between capital cities $(n=71$, mean $r a n k=76.11)$ and regional/countryside $(n=64$, mean rank=59.00) $(\mathrm{U}=1696.000$, $\mathrm{Z}=-2.811 \mathrm{p}=.005, \mathrm{r}=0.16$ )

Q20. I choose online learning as a learning method to improve English.
- Between capital cities $(n=71$, mean rank=38.00) and minority zones $(n=8$, mean $\operatorname{rank}=57.75)(\mathrm{U}=142.000, \mathrm{Z}=-2.484 \mathrm{p}=.013$ $\mathrm{r}=0.14$ )

- Between general cities $(n=176$, mean rank=90.66) and minority zones $(n=8$, mean $\operatorname{rank}=133.00)(\mathrm{U}=380.000, \mathrm{z}=-2.470$, $\mathrm{p}=.014, \mathrm{r}=0.14)$

- Between regional/countryside $(n=64$, mean $r a n k=34.47)$ and minority zones $(n=8$, mean $\operatorname{rank}=52.75)(\mathrm{U}=126.000, \mathrm{Z}=-2.718$, $\mathrm{p}=.007, \mathrm{r}=0.15)$
Q25 I am responsible for choosing English activities outside of class.
- Between capital cities $(n=71$, mean rank=146.03) and general cities $(n=176$, mean $\operatorname{rank}=115.11) \quad(U=4684.000, \quad Z=-3.407$, $\mathrm{p}=.001, \mathrm{r}=0.19)$

- Between capital cities $(n=71$, mean rank=76.73) and regional/countryside $(n=64$, mean $r a n k=58.31) \quad(U=1652.000$, $\mathrm{z}=-3.035, \mathrm{p}=.002, \mathrm{r}=0.17$ )

Q26 I am responsible for monitoring English learning progress by using various strategies.
- Between capital cities $(n=71$, mean rank=137.72) and general cities $(n=176$, mean $r a n k=118.47) \quad(U=5274.000, \quad Z=-2.012$, $\mathrm{p}=.044, \mathrm{r}=0.11)$

- Between capital cities $(\mathrm{n}=71$, mean $r a n k=79.52)$ and regional/countryside $(n=64$, mean $r a n k=55.22) \quad(U=1454.000$, $\mathrm{z}=-3.757, \mathrm{p}=.000, \mathrm{r}=0.21$ )

- Between general cities $(n=176$, mean $r a n k=127.42)$ and regional/countryside $(n=64$, mean $\operatorname{rank}=101.46) \quad(\mathrm{U}=4413.500$, 
$\mathrm{z}=-2.677, \mathrm{p}=.007, \mathrm{r}=0.15)$

Q29 I am responsible for correcting mistakes by myself.
- Between capital cities ( $\mathrm{n}=71$, mean rank=75.11) and regional/countryside $(n=64$, mean rank=60.12) $\quad(\mathrm{U}=1767.500$, $\mathrm{z}=-2.429, \mathrm{p}=.015, \mathrm{r}=0.14)$

- Between general cities ( $\mathrm{n}=176$, mean rank=126.80) and regional/countryside $(\mathrm{n}=64$, mean rank $=103.18)(\mathrm{U}=, 4523.500$, $\mathrm{z}=-2.581, \mathrm{p}=.010, \mathrm{r}=0.14)$

Q33 I evaluate my English learning - Between capital cities $(n=71$, mean rank=76.42) and regularly. regional/countryside $(n=64$, mean $\operatorname{rank}=58.66) \quad(\mathrm{U}=1674.000$, $\mathrm{z}=-2.824, \mathrm{p}=.005, \mathrm{r}=0.16$ )

Q36 I would like my English teachers to evaluate my English learning.

- Between capital cities ( $\mathrm{n}=71$, mean $r a n k=77.18)$ and regional/countryside $(\mathrm{n}=64$, mean rank $=57.81) \quad(\mathrm{U}=1620.000$, $\mathrm{z}=-3.037, \mathrm{p}=.002, \mathrm{r}=0.17)$

- Between general cities $(\mathrm{n}=176$, mean rank=128.03) and regional/countryside $(\mathrm{n}=64$, mean rank=99.80) $(\mathrm{U}=4307.000$, $\mathrm{z}=-2.945, \mathrm{p}=.003, \mathrm{r}=0.16$ )

A larger number of activities regarding students' learner autonomy ability were found to be statistically significant differences on their secondary education locations in contrast to their primary education locations. Although the results showed that all the values of the effect sizes were small, secondary education plays a more important role in their long-term learner autonomy development. Furthermore, the result reveals that a more stable number of participants who chose to complete both primary education and secondary education in the same place were from capital cities and minority zones. However, more participants who completed primary education in regional areas would like to relocate to general cities to finish their secondary education. From this point of view, to achieve higher scores in the competitive environment, Chinese families have paid more attention to children's secondary education.

\subsection{Qualitative Stage}

A case study requires "extensive material from multiple sources of information to provide an in-depth picture of the case" (Creswell, 2007, p. 96). Data sources included the participants' reflective writings, teaching plans, guidelines of the current secondary English curriculum, learning materials and open interviews. The two cases were stratified cases that were chosen from the 10 volunteering participants as this kind of sample is to "generalize for specially selected subgroups within the population" (Flyvbjerg, 2013, p. 182). When selecting the samples, researchers paid attention to choose ordinary and accessible cases rather than extreme, unusual and critical cases (Creswell, 2013). The student case was a postgraduate student with 11 years' English learning experience and he had more profound perceptions in English learning than many other undergraduate students. The teacher case was his previous English teacher in a privileged secondary school who has been teaching in the same school for more than 10 years. From the multiple sources of data, the following three main themes emerged in the study.

\subsubsection{Priority}

Xiaofei (Anonymous) is a 23 year old postgraduate student majoring in Technology at the university. He was born and grew up in a countryside where poverty is still endemic. In his family, he has two elder sisters and a grandfather who was suffering from severe sickness. Six people lived in a shabby bricked village house. He reflected upon unforgettable fragments in his childhood:

....as the inconvenient transportation in the village, the only chance of my family members came to a small city nearby was the third Sunday of every month. This date was called 'Farmer's day' and children in big cities might 
have never had a chance to see it. At that time, it was the biggest 'festival' for me because I would have chance to request my parents to buy tasty food and a small toy for me. My two sisters would seldom have an opportunity to go with me as my grandfather often told my parents to ask them to offer the 'best' to me. In my age, it is too difficult for me to understand the implied meanings of the 'best'. Later on, when I came to the school age, I gradually understood my position in the family.

... I intended to help my sister in cropping wheat so that I finished all my homework at school on that day. After school, I run directly to the farm and yelled to my sister. At the beginning, she was stunned. After a short moment, she realized that I came along to help her with her farm job. She felt so happy and we worked together for a couple of hours before dark. However, she did not realize that she would be severely beaten by parents after I assisted her. On the way back home, I told jokes I learnt from other friends in the school and she listened carefully. Without any responses from her, I only felt that she casted an admiring eye on me. Suddenly, I felt sympathetic and told my sister that I wish I could go to school with her.

When we came back home, my parents did not say anything. By the door, she was slapped by my dad, which made her burst into crying. I was shocked and frozen until my mother scolded her 'I told you so many times that your brother would be our hope and not to ask him to do any job. That is your task'. Upon hearing those words, my body was twisted just like I was electrocuted...

In Xiaofei's family, he is the only son and his grandfather's traditional idea had a long-term educational influence on his parents. He was regarded as the only 'hope' of the family and his two elder sisters could not go to schools as the family could only afford for the son to attend. Also, a large amount of family jobs and farm jobs were added to his sisters' burden. For Xiaofei, his task is to study hard to achieve a satisfying score in all kinds of examinations. In most schools, scores in examinations are the only criterion for measuring whether students are elite and whether the teacher is successful. This priority is also sourced from his English teacher, Mrs. Li (Anonymous), who has obtained a substantial number of awards from schools, provinces and the nation as well. She is regarded as one of the best teachers in Xiaofei's secondary school.

In the interview, she expressed that:

The school is a high-ranking secondary school that included both junior and senior high education. The school is located in a southern general city in China. Most students were regarded as 'elite' as they were chosen from small villages and counties nearby. Hence, ever year, over $95 \%$ of graduates could be accepted into a top university in China. Because of this high acceptance rate into the university, teachers have their own priority on daily-teaching. As required by the MOE, teachers need to pay attention to the individual's learning style in order to support the students with adaptable learning strategies. However, in reality, teachers and students were only offered 40 minutes in the class everyday to finish a lesson that was composed of passage listening, article reading, and assignment feedback.

Mrs. Li showed one part in her recent lesson plan as an example (Figure 2). In her teaching plan, she utilised PPTs and ICT as tools to explain the main idea of Christopher Reeve's story. Also, she tried to increase students' communicative skills by implementing five minutes' group discussion in her class. Students in pairs took turns to talk about the superhero's life experience. However, from the teaching materials and assignments, the focus was still on enhancing reading and writing skills, which drill students' literacy and grammatical skills. (See Task 5 and Task 6 in the following pictures). 


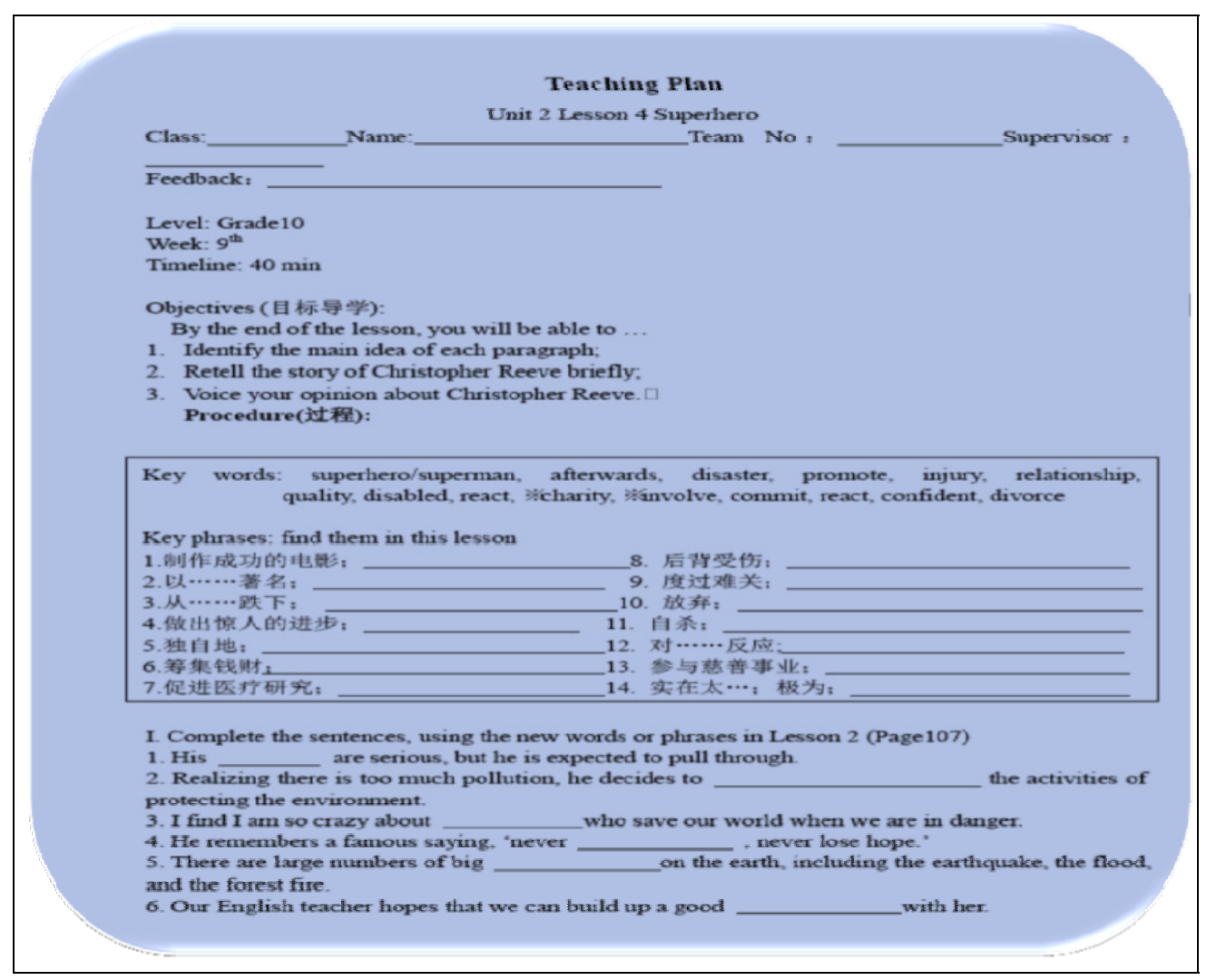

Figure 3. One part of Mrs. Li's teaching plan

Task 5. Imagine you are a reporter from CCTV-1, who is going to introduce Christopher's story, please write a short report about 40 words.

\section{$\underline{\text { The passage tells us }}$}

Figure 4. Summary writing 
Task 6

Position(定 $f_{\mathrm{y}}$ ) the key word 'superheroes' to find out more information related to it.

Imagination and fantasy can play an important role in achieving the things we fear. Children know this very well. Fred Epstein, in his book if I Make it to Five, tells a story he heard from one of friends about Tom, a four-year-old boy with a cancer in his back bone. He came through several operations and a lot of pain by mastering his imagination.

Tom loved to pretend, and he particularly loved to play superheroes, Dr. Epstein explained that it was actually a brilliant way for his young mind to handle the terrifying and painful life he led.

The day before his third trip to the operating room, Tom was terribly afraid. "Maybe I could go as Superman," he whispered to his mom. Hearing this, the mother hesitated for a while. She had avoided buying the expensive costume( $x_{t}(t)$ ), but finally she agreed.

The next day Tom appeared as the powerful superman, showing off through the hospital halls and coolly waving his hand to the people greeting him along the way. And Tom. with the strength of his fantasy, successfully made it through the operation.

The power of imagination need not be reserved for children only. We all have the power to use our fantasies to attempt things we never thought possible, to go through those things that seem impossible, and to achieve what we never believed we could, Just as Dr. Epstein puts it ,"If you can dream it, you can do it".

It doesn't mean that you should dress as a superhero for you next job interview. But, next time you are tested in a way that seems impossible, imagine what it would take to overcome it. Become the person you need to become to win over your challenge and do it in your mind first. So, let your imagination run wild, and dare to dream.

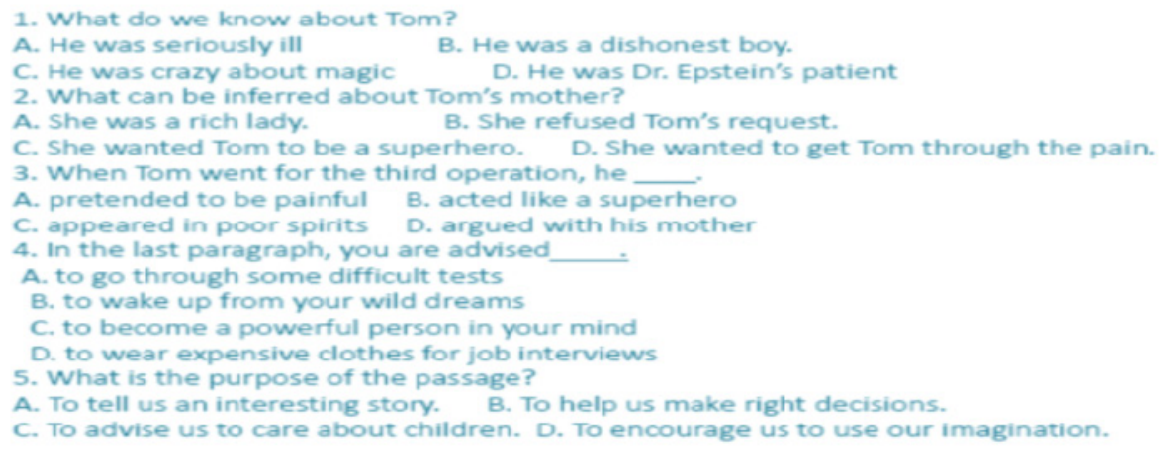

Figure 5. Passage reading

Mrs. Li commented that although the school principal emphasized that teachers should utilise PPTs and ICT to be aligned with the guidelines required by the MOE, the timeline was limited. Therefore, the priority is to put effort into improving students' writing and reading proficiency to assist them in achieving a better academic performance in examinations.

\subsubsection{Identity}

During the open interview session, Xiaofei discussed that he often reflected and had deep thoughts in terms of his identity. According to him, the meaning of identity is not where he comes from, nor his nationality. He regarded identity as a feeling mixed with unwillingness, struggling, and confusion in the reality that forces him to follow. He used a variety of body language to express his identity. For example, when he talked about the experiences of how he was chosen from the primary school in the village to a high ranking secondary school in the city, his facial expression was mixed with appreciation, sweetness, and persistence. However, when our topic shifted to his English learning at university, he felt a little apprehensive and put his hands on hips and sighed:

In the secondary school, most teachers regarded that the only task for them was to assist students to obtain a satisfying score for the College Entrance Examination. Consequently, I realized that the only task was to achieve a high score so that I could be accepted in to a top university in China. I was expected to be good enough...

When he was asked to clarify what the extent of 'good enough' is in his opinion, he answered:

...It is hard to say! For example, if I got 90 (100 is a full score) in the final term English examination, my teachers, parents and the school principal would expect me to get over 90 in the following English examination. However, if I got 88 in the following English examination, I was out of their expectations. You know, I was always expected to be closer to the full mark but it is really difficult for me.

Xiaofei commented his English learning experiences at university as follows:

Although no one pushed me to achieve a full mark in English examinations, I was often out of breath. Being fully occupied by all kinds of unwilling activities, I cannot be myself. For example, my English writing was 
good enough so that I was persuaded many times by the mentor to participate in an English writing club. This club had weekly meetings and every member needed develop new members. I needed to support my sisters as they contributed their early to late time to help me when I was in the school. As a consequence, besides these activities out of my willingness, I needed to finish two part-time tutoring jobs. Fortunately, my jobs were closely related to my discipline...

The English learning environment was relaxed. I was treated as an independent learner. My English teacher lectured us four hours every week and the rest of time I could go to the English Language Self-Access Learning Center to improve my English skills. On the online platform, I was able to access a large number of resources regarding speaking, listening, reading and writing. However, these resources were only related to the English textbook. In other words, I was not allowed to access the other online platform resources.

Apart from Xiaofei's comments, Mrs. Li also discussed her concerns on developing learner autonomy in the secondary school:

Using diverse teaching methods to motivate students' interest was documented in the current curriculum reform; consequently, it is necessary to develop learner autonomy as it is an essential part in their life-long learning. I believed it is important to both teachers and students in the school. However, driven by achieving high scores in the College Entrance Examinations, my teaching performance is only assessed by the students' scores. Say, a grade has 10 classes with over 600 students. Not only does the student need to be competitive in monthly examinations but each English teacher needs to be ranked based on the monthly examination result. In June, all of us need to be evaluated by students' performances based on their College Entrance Examination report.

At this moment, rote-learning for Chinese students who are in the examination oriented system is traditionally dominant among school teachers, students and parents. Chinese parents also believed that overwhelming assignments after schools must be beneficial for their children. If I asked students to finish role-plays as their homework rather than asking them to use new vocabularies to make sentences, their parents were highly likely to make complaints to the school principal doubting whether I was qualified enough in teaching at a secondary school.

\subsubsection{Quality or Quantity?}

Mrs. Li unfolded the guidelines of the current secondary English curriculum and she pointed out a very interesting point: "There are all kinds of numbers that were the criterion to evaluate how fast students are able to finish a passage, how many vocabularies they have mastered, and how fluently they need to speak". She expressed her worries on how far these numbers can go and how effectively the parts play in students' evaluation. She took Xiaofei as an example:

When Xiaofei was in the secondary school, he was able to achieve a high score in English examinations. Particularly, he had a good command of word usage. However, he was so afraid of being called out to speak English in front of us. You know, he was very introvert, shy and sensitive as his family is in poverty. This had an influence on his early childhood education. In his village, qualified English teachers were scarce, let alone learning English from an early stage. As such, it is very difficult to say Xiaofei is a qualified student to meet all the requirements with the appropriate criteria in the guidelines. However, traditionally, he is a qualified student as he was accepted into a top university with a rather high score in the College Entrance Examination.

Mrs. Li proposed that we should consider the relationship between the quality of education and the increased needed number index to measure a student and how to balance the two. She criticized the idea of 'ultra left and ultra right' which appeared during the Chinese Cultural Revolution.

Compared with the emphasis in quantity, Xiaofei regarded the university as overemphasizing the quality of education in English teaching and learning. He reflected that developing students' learner autonomy and communicative skills were indeed essential in the long-term quality education programme. However, most university students have been taught over 10 years by a rote-learning method. As a consequence, it seems that students felt it was difficult to transit from a restricted learning environment to a more independent and free learning context at university. He proposed that a transition programme should be provided to bridge between the quality education and quantity index in schools and universities.

\section{Discussion}

The first research question has been fully addressed by both the quantitative and qualitative research result. The participants' locations where they finished their basic education had a positive correlation with their learner autonomy development at university level. More activities related to their learner autonomy development on their secondary school locations were found to have statistically significant differences compared with those on 
their primary education locations. More specifically, the statistically significant differences were found on two activities related to determining learning objectives and monitoring evaluation in terms of the participants' primary education locations. However, there were eight activities that were found to have statistically significant differences on the locations where participants finished secondary education rather than primary education across the five specific criteria proposed by Holec (1981). Although the effective sizes are all small, the participants' secondary school locations played a more important role in terms of their learner autonomy development at university. Aligned with Traub's (2014) study, Chinese families have paid much attention to children's education in high schools because of the competition in the College Entrance Examination.

The case study research result indicated that teachers, parents and students paid more attention to aspects of secondary education compared with that of primary education in China. Xiaofei greatly appreciates being chosen from his village school to the top secondary school in the city. He expressed that this was the first turning point in his life. Driven by the Chinese traditional ideology, 'The male is in charge of earning money to support the family, while the female is responsible for doing housework', he was born with substantive responsibilities. While he appreciates the honour of being chosen he accepts that there is also pressure from expectations. Also, compared with his two elder sisters, all the family members wished and expected for his successful academic achievement in schools. This result was aligned with Throssell (2011) and Jiang's research (Jiang, Lu, \& Throssell, 2012). Jiang et al. (2012) discussed that Chinese parents' aspirations were for their children to be talented and successful academically and this desire has a long-term influence on children's education. Particularly, with a long-term cultural influence of Confucianism, boys are expected to hold a dominant role both inside and outside of families.

The second research question was focused upon within the qualitative research results. Significant challenges that emerged were the high stake-examination orientated system, overemphasizing quantity through linkages to test and examination scores, and a lack of qualified English language teachers in rural areas. Xiaofei used his body language to express that he often felt confused and was not sure of his identity. He felt pressured from being throughout education as a primary student and this continued until the university but he was eager to have his own interest in his free time. In reality, his time was filled by unrelenting examination papers and a large amount of homework. This response was not in accordance with the research undertaken by Rodrigues (2004), who claimed that Chinese students preferred to be taught passively. Mrs. Li explained that she tried to implement various innovative learning activities and teaching methods proposed by the guidelines into her classroom. However, limited time and high competition for students and teachers were challenges in her teaching practice. A similar research result was found in Lu's (2014) study, which presented that Chinese school teachers had a significant academic pressure from promotion, students' evaluation, and students' examination performance. This particularly relates to those who are teaching students in the last year at secondary school as they face a more significant challenge in students' academic achievement in the College Entrance Examination. This research finding is also supported by Thompson and Gui (2000), who argued that teaching methods that originated from the West might not fit into the Chinese context. Apart from these challenges, highlighted by Xiaofei and his teacher's reflections, ICT was utilised in schools but it was not widely utilised in China, which was contrary to the research result found by Zhang et al. (2010). Li and Ni (2012) claimed that a lack of qualified teachers with proper ICT skills are still the main challenges in Chinese regional schools. They believed that the guidelines in the new curriculum were too ideal to be realized in a short period.

The third research question was also addressed by the qualitative research result. The major challenge highlighted was the incompatible linkage between the policy and practice. As mentioned in the previous section, this top-down curriculum reform $(\mathrm{Hu}, 2003)$ would bring substantial benefits to both students and teachers if it was not idealised. However, practically, teachers, students, parents and school principals felt pressured by the College Entrance Examination and this has becoming a 'commander' in China's educational system. With the influence of this commander, schools and parents are concerned about simply marks instead of knowledge and skills transition. As a consequence, when high school students were accepted into university and exposed to a more open, relaxed and free learning environment, they might experience difficulty in acquiring knowledge from being taught passively to learning it actively. Moreover, overemphasizing marks might hinder students to develop their autonomy in high schools and this ability is linked with students' life-long learning, learning styles, and learning strategies. All these are related to students' academic performance and their future success.

In this regard, the author proposes changing from a 'How' to a 'Have-A-Go' model. More specifically, previously, researchers and the MOE explored the curriculum guidelines on a 'How' model, such as how to improve students' learner autonomy and how to enhance students' English vocabularies. The study also reveals that teachers felt difficult to follow the curriculum guidelines issued by the MOE, which have addressed the 
'How' model. However, this research suggests that it is important to seek a balance between the requirements in the new Curriculum and daily teaching practice as an essential element in the current round of China's basic education reform and future development in terms of students' quality, learner autonomy and lifelong learning. Particularly, a foundation programme is proposed to be constructed for freshmen at universities. This could assist students transitioning more smoothly from schools to university as students' transition process plays a pivotal role in their future academic achievement, wellbeing, and lifelong learning. The author endeavours to suggest a "Have-A-Go" model should be geared with three main strengths: the central government, practitioners (teachers, school principals, and educators), and families. Traditionally, Chinese educational reforms were in a top down hierarchical model $(\mathrm{Hu}, 2003)$, which presents an overcentralisation of power. However, in the reform process, the bottom base was so flexible that it might not be supportive. This three geared model endeavours to balance the power from the three parts and all are needed in a coherent cyclical status.

\section{Conclusion}

Overall, the research findings reveal significant differences between students' locations where they finished primary education, and secondary education with regard to their choices of examining their learner autonomy development at university. These differences are apparent in regard to students' basic education locations. Eight questionnaire items related to students' learner autonomy making abilities found statistically significant differences regarding participants' secondary school locations compared with the two items which were found to be statistically significantly different in regard to their primary school locations. These findings were demonstrated in both the quantitative and qualitative stages of the study.

Although this study uses the English course as a case, barriers that are highly likely to hinder the development of learner autonomy in Chinese basic education are further discussed. These include the focus on marks in tests and examinations as a basis for measuring the success of students and teachers. The emphasis on marks tends to restrict teaching and learning strategies. All of these factors may influence students' learner autonomy development in long-term quality education implementation, which has been emphasised in the current round of China's Basic Education Curriculum Reform. In order to accelerate China's education reform, a 'Have-A-Go' model has been proposed by the author. From a top-down model to a three-geared tiered model, the author expects that Chinese students could achieve significant levels of success through the strategy of 'invigorating the country through science and education' initiated by the central government.

\section{References}

Benson, P. (2011). Teaching and researching autonomy in language learning (2nd ed.). London: Longman.

Bogdan, R., \& Biklen, S. (1982). Qualitative research for education: An introduction to theory and methods. Boston, MA: Allyn and Bacon.

Chow, I. H. S. (1995). Management in Hong Kong: Needs and challenges. International Journal of Educational Management, 9(5), 10-15. http://dx.doi.org/10.1108/09513549510095068

Creswell, J. (2013). Qulitative inquiry research design (3rd ed.). London: Sage.

Creswell, J. W. (2007). Qualitative inquiry and research design: Choosing among five approaches (2nd ed.). Thousand Oaks, CA: Sage.

Dam, L. (1995). Learner autonomy: From theory to classroom practice. Dublin: Authentik Language Learning Resources.

Dörnyei, Z. (2009). The L2 motivational self system. In Z. Dörnyei, \& E. Ushioda (Eds.), Motivation, language identity and the L2 self (pp. 9-42). Bristol: Multilingual Matters.

Eisenhardt, M. K. (2002). Building theories from case study research. In M. Huberman, \& B. M. Mile (Eds.), The qualitative research companion (pp. 5-35). Thousand Oaks, CA: Sage Publications.

Epstein, J., Osborne, R. H., Elsworth, G. R., Beaton, D. E., \& Guillemin, F. (2015). Cross-cultural adaptation of the Health Education Impact Questionnaire: Experimental study showed expert committee, not back-translation, added value. Journal of Clinical Epidemiology, 68(4), 360-369. http://dx.doi.org/10.1016/j.jclinepi.2013.07.013

Eurydice. (2008). Higher education governance in Europe Belgium: European Commission.

Flyvbjerg, B. (2013). Case study. In N. Denzin, \& Y. Lincoln (Eds.), Strategies of qualitative inquiry. London: Sage.

Gao, Y. H., Zhao, Y., Cheng, Y., \& Zhou, Y. (2007). Relationship between English learning motivation types and 
self-identity changes among Chinese students. TESOL Quarterly, 41, 133-155. http://dx.doi.org/10.1002/j.1545-7249.2007.tb00043.x

Holec, H. (1981). Autonomy and foreign language learning. Oxford: Pergamon.

$\mathrm{Hu}$, G. (2003). English language teaching in China: Regional differences and contributing factors. Journal of Multicultural and Multilingual Development, 240-318. http://dx.doi.org/10.1080/01434630308666503

Jiang, H., Lu, J., \& Throssell, P. (2012). The application of family-based early interventions in the YRD, China: A project based on two case studies. Theory and Practice in Language Studies, 2(12), 2483-2490.

Lai, C., \& Lin, X. (2015). Strategy training in a task-based language classroom. The Language Learning Journal, 43(1), 20-40. http://dx.doi.org/10.1080/09571736.2012.681794

Li, Q., \& Ni, Y. (2012). Debates on the basic education curriculum reform and teachers' challenges in China. Chinese Education and Society, 45(4), 9-21.

Lu, J. (2014). English Language Learning and Teaching in China - Students' Perspectives. New York: Untested Ideas Research Center. http://dx.doi.org/10.5539/elt.v7n4p74

Ma, Z., \& Ma, R. (2012). Motivating Chinese students by fostering learner autonomy in language learning. Theory and Practice in Language Studies, 2(4), 838-842. http://dx.doi.org/10.4304/tpls.2.4.838-842

Ministry of Education. (2001). Basic education curriculum reform (trial version). Beijing, China.

Ministry of Education. (2004). Zhongguo Jichujiaoyu Fazhan Zhanwang. Retrieved from http://www.moe.edu.cn/publicfiles/business/htmlfiles/moe/moe_163/200408/2907.html

Paine, L., \& Fang, Y. P. (2006). Reform as hybrid model of teaching and teacher development in China. International Journal of Education Research, 45, 279-289. http://dx.doi.org/10.1016/j.ijer.2007.02.006

Pallant, J. (2013). SPSS survival manual (5th ed.). England: Allen \& Unwin.

Rodrigues, C. A. (2004). The importance level of ten teaching/learning techniques as rated by university business students and instructors. Journal of Management Development, 23(2), 169-182. http://dx.doi.org/10.1108/02621710410517256

Ryan, J., Kang, C., Mitchell, I., \& Erickson, G. (2009). China's basic education reform: An account of an international collaborative research and development project. Asia Pacific Journal of Education, 29(4), 427-441. http://dx.doi.org/10.1080/02188790903308902

Sargent, T. (2011). New Curriculum reform implementation and the transformation of educational beliefs, practices, and structures: A case study of Gansu province. Chinese Education and Societ, 44(6), 49-74. http://dx.doi.org/10.2753/ced1061-1932440604

Stracke, E. (2012). Peer learning and learner autonomy in EFL student-teacher education in China and Vietnam. New Zealand Studies in Applied Linguistics, 18(2), 35-44.

Tang, M., \& Tian, J. (2015). Associations between Chinese EFL graduate students' beliefs and language learning strategies. International Journal of Bilingual Education and Bilingualism, 18(2), 131-152. http://dx.doi.org/10.1080/13670050.2014.882882

Teddlie, C., \& Tashakkori, A. (2010). Overview of contemporary issues in mixed methods research. In A. Tashakkori, \& C. Teddlie (Eds.), Handbook of mixed methods in social \& behavioral research (pp. 1-41). California: Sage. http://dx.doi.org/10.4135/9781506335193.n1

Thompson, E. R., \& Gui, Q. (2000). International Perspective: The Appropriateness of Using Hong Kong to Make Inferences About Business Students in Mainland China. Journal of Education for Business, 76(1), 48-55. http://dx.doi.org/10.1080/08832320009599050

Throssell, P., \& Zhao, Y. (2011). Speech act theory and its application to EFL teaching in China. Language, Culture and Society, 32, 88-95.

Traub, D. (2014). Shanghai High Confidential. Newsweek Global, 162, 1-12.

van de Vijver, F., \& Leung, K. (1997). Methods and data analysis for cross-cultural research. Thousand Oaks, CA: Sage.

Yang, X., Shi, F., Liu, X., \& Zhao, Y. (2015). Learning styles and perceptual patterns for English /i/ and /I/ among Chinese college students. Applied Psycholinguistics, $36, \quad$ 1-29. 
http://dx.doi.org/10.1017/S014271641500020X

Zhang, J., Fang, Y., \& Ma, X. (2010). The latest progress report on ICT application in Chinese basic education. $\begin{array}{llll}\text { British Journal of Educational Technology, } & 41(4),\end{array}$ http://dx.doi.org/10.1111/j.1467-8535.2010.01083.x

Zhang, Q., \& Kim, T.-Y. (2013). Cross-grade analysis of Chinese students' English learning motivation: A mixed-methods study. Asia Pacific Education Review, 14(4), 615-627. http://dx.doi.org/10.1007/s12564-013-9288-3

Zhao, H., \& Coombs, S. (2012). Intercultural teaching and learning strategies for global citizens: A Chinese EFL $\begin{array}{lllll}\text { perspective. Teaching in Higher } & \text { 245-255. }\end{array}$ http://dx.doi.org/10.1080/13562517.2011.611874

\section{Note}

Note 1. This number is obtained from Ministry of Education of the People's Republic of China Website: http://www.moe.edu.cn/

\section{Copyrights}

Copyright for this article is retained by the author(s), with first publication rights granted to the journal.

This is an open-access article distributed under the terms and conditions of the Creative Commons Attribution license (http://creativecommons.org/licenses/by/3.0/). 